\title{
Assessment of Infant and Young Child Feeding Content in Physicians' Postgraduate Textbooks in Croatia
}

\author{
Anamarija Ćuže Gugićn ${ }^{1}$ Irena Zakarija-Grkovićn \\ ${ }^{1}$ Health Centre of Split and Dalmatia County, Split, Croatia ${ }^{2}$ University of Split School of Medicine, Departments of Family \\ Medicine and Clinical Skills, Split, Croatia
}

Correspodence: irena.zakarija-grkovic@mefst.hr; Tel.: + 38521557 823; Fax.: + 38521557811

Received: October 10, 2019; Accepted: December 13, 2019

\begin{abstract}
Objectives - Physicians who care for mother-baby dyads should receive training in infant and young child feeding. This should be reflected in the official postgraduate medical curriculum and in the relevant textbooks. The aims of this study were to: 1) determine if infant and young child feeding is part of physician postgraduate training programs in Croatia; 2) assess the infant and young child feeding content of relevant textbooks. Methods - Post-graduate training programs in obstetrics/gynaecology, paediatrics and family medicine, available online, for the academic year 2016/7 were analysed. Eight relevant textbooks were assessed by two independent authors. Topics covered in World Health Organisation's Infant and young child feeding Model Chapter for textbooks for medical students and allied health professionals were used as a "gold standard". Results - Infant and young child feeding is part of family medicine and paediatric postgraduate training programs in Croatia, with one and four subjects dedicated to this topic, respectively. Six percent (range: $3.3-10.0$ ) of infant and young child feeding content was found to be inaccurate, and $72 \%$ of topics were omitted. The topic Animal milks and infant formula was thoroughly covered, whereas Twins, Oversupply of breast milk, Relactation, Kangaroo Mother Care and Fostering breastfeeding support groups was omitted in all textbooks. Conclusion - A thorough revision of infant and young child feeding content in Croatian physician postgraduate training programs is required if family physicians, paediatricians and obstetricians/gynaecologists are to provide appropriate advice and support to mother-infant dyads.
\end{abstract}

Key Words: Infant and Young Child Feeding - Education - Physicians - Croatia - Model Chapter - Breastfeeding.

\section{Introduction}

Optimal infant and young child feeding (IYCF), starting with breastfeeding, is the basis for future health, prosperity, equity and sustainability (1). Breastfeeding can prevent an estimated 823000 child deaths and 20000 breast cancer deaths every year (2). Despite this, breastfeeding rates globally are below recommended levels, with only $37 \%$ of infants younger than 6 months being exclusively breastfed (2). In Croatia, only $8 \%$ of women are exclusively breastfeeding at 6 months and $22 \%$ of women are providing any breast milk to their children at 12 months of age (3), despite the World
Health Organisation's (WHO) recommendation to breastfeed until two years of age. In recognition of this, the World Health Assembly has set a goal of increasing the rate of exclusive breastfeeding (EBF) to at least $50 \%$ by 2025 . To enable more women to breastfeed, it is vital that healthcare professionals, especially physicians, given their position of authority and access to patients, have a basic understanding of IYCF so that they can support mothers and families achieve personal infant feeding goals. This can be facilitated if physicians receive education in IYCF that is evidence-based, comprehensive, patient-centred and up-to-date. 
IYCF education among physicians has been poorly taught in the past, leading to insufficient knowledge (4-6). Freed, in his national survey, found that paediatric residency training in the USA failed to prepare doctors for their role in breastfeeding promotion (7). Zakarija-Grković and Burmaz found, in their survey of 5 maternity hospitals in Croatia, that $47 \%$ of maternity staff would inappropriately recommend partial or complete cessation of breastfeeding if a mother had mastitis (8). To determine why this is the case, some researchers have explored the content of textbooks used by physicians. Ogburn and Philipp analysed commonly used paediatric and obstetric textbooks in USA, and found that breastfeeding information was highly variable, inconsistent and contained many omissions $(9,10)$. Textbooks used for the training of Croatian health professionals who care for mothers and infants have not been analysed so far.

Given the influence and opportunity obstetricians, paediatricians and family doctors have in protecting, promoting and supporting breastfeeding in Croatia, we decided to ascertain if IYCF is part of the national curriculum for post-graduate training in obstetrics/gynaecology $(\mathrm{O} \& \mathrm{G})$, paediatrics and family medicine, and whether textbooks used in these programs contain accurate information on IYCF.

\section{Methods}

\section{Design}

We used a cross-sectional study design to determine if IYCF is part of the national curriculum for postgraduate education in $\mathrm{O} \& \mathrm{G}$, paediatrics and family medicine in Croatia, and to find out which textbooks are relevant for this purpose.

\section{Setting}

In Croatia, primary health care is provided by family doctors, paediatricians and O\&Gs. Every adult has his/her own family doctor, every woman has her own O\&G and every pre-school child is cared for by a paediatrician. These specialists have the great- est influence on a mother's IYCF practice. O\&Gs can impact on a mother's feeding choice early in pregnancy; paediatricians are the first physicians a mother will turn to in the postnatal period, while family doctors provide integrated care for the mother and her family. In Croatia, postgraduate physician training in family medicine lasts 4 years, whereas training in $\mathrm{O} \& \mathrm{G}$ and paediatrics lasts 5 years. Each training program includes postgraduate university-based education, which is conducted at the University of Zagreb, Croatia.

\section{Sample}

We targeted all university courses which are part of the national postgraduate training program in O\&G, paediatrics and family medicine in Croatia, and included all relevant textbooks that could potentially include information on IYCF. We excluded textbooks obviously unrelated to IYCF, such as those on ultrasound, gynaecological surgery etc. We did not evaluate optional reading materials or handouts.

\section{Measurement}

We used the WHO Infant and young child feeding Model Chapter for textbooks for medical students and allied health professionals (Model Chapter) (11) as the "gold-standard" for assessing information on IYCF in selected textbooks. The Model Chapter, through nine sessions, covering 88 topics, provides basic information about nutritional needs and feeding practices in children less than 2 years of age. It is written so that health professionals learn how to counsel women and help solve feeding difficulties, plus know when to refer a mother with complex feeding problems. Each textbook was searched thoroughly, and sections relevant to IYCF read carefully and compared with the Model Chapter. Each of the 88 topics listed in the Model Chapter was then assessed using the same scoring system as published in Ogburn's study (9): correct and thorough $(\mathrm{CT})$, correct and brief $(\mathrm{CB})$, incorrect $(\mathrm{I})$ or omitted $(\mathrm{O})$. 'Total correct' referred to 
the sum of CT and CB. In addition to the 88 topics in the Model Chapter, we also looked at the accuracy of photographs. The topic Evidence for recommended feeding practices, which refers to evidence supporting the health advantages of optimal IYCF, is presented as one topic in the Model Chapter; in our study we divided this into two topics: maternal health and child health. In total we assessed 90 topics. The denominator for each session varied depending on the number of topics covered in each session, e.g. session one has six topics, therefore a total of 48 scores were possible for the 8 textbooks assessed (see Table 1).

\section{Data Collection}

Data were collected by two authors, a family doctor and International Board Certified Lactation Consultant, and a family medicine trainee, who had completed a 90-hour IYCF course. In November 2016, postgraduate curricula in paediatrics, $O \& G$ and family medicine were accessed via the internet for the academic year 2016/7. Each curriculum was thoroughly searched for any IYCF-related subjects and relevant textbooks. Relevant textbooks were independently assessed by study authors and any scoring discrepancies that arose were discussed and agreed upon.

\section{Statistical Analysis}

Data were entered into an Excel worksheet and analysed using descriptive statistics. Inter-rater reliability, i.e. the degree of agreement among assessors, was calculated to determine how much homogeneity or consensus existed in the ratings given by study authors. Statistical method used was Cohen's kappa $(\kappa)$, a statistic used for qualitative, i.e. categorical data, where two raters independently classify $N$ items into $C$ mutually exclusive categories. If the rates are in complete agreement, then $\kappa=1$. If there is no agreement among the raters, other than what would be expected by chance, then $\kappa=0$. MedCalc statistical software (MedCalc Software, version 17.1, Ostend, Belgium) was employed for data analysis.

\section{Results}

IYCF in Paediatric, Family Medicine and Obstetric National Training Programs in Croatia

IYCF was listed as part of the paediatric and family medicine training programs in Croatia, with four subjects (3 compulsory, 1 elective) and one subject (compulsory) encompassing this topic, respectively. In the family medicine program, IYCF was taught as part of the subject 'Child and adolescent health', whereas in the paediatric training program IYCF was covered in 'Preventive and social paediatrics', 'Neonatology', 'Paediatric gastroenterology' and 'Nutrition in health and disease'. Although we did not find any mention of IYCF in the official O\&G training program, three relevant textbooks on perinatal care were found to contain information on IYCF.

\section{Assessment of Relevant Textbooks}

A total of 8 textbooks were assessed: 2 in family medicine, 3 in paediatrics and 3 in O\&G. Texts included were: Family Medicine (12), Textbook of family medicine (13), Paediatrics (14), Paediatric gastroenterology (15), Nelson Textbook of Pediatrics (16), Obstetrics (17), Obstetrics (18) and Gynaeco$\log y$ and perinatology (19). All textbooks were in Croatian, apart from Nelson Textbook of Pediatrics, which was in English. A summary of scores for individual textbooks is shown in Fig. 1. Full assessment of included textbooks is shown in Table 1 . The inter-rater reliability for the assessed textbooks ranged between 0.587 and 0.936 , indicating moderate to almost perfect agreement. The top five sessions most frequently covered in textbooks were: The importance of infant and young child feeding and recommended practices $(\mathrm{N}=18 / 48 ; 38 \%)$, Maternal health ( $\mathrm{N}=16 / 48 ; 35 \%)$, Management and support of infant feeding in maternity facilities $(\mathrm{N}=16 / 56 ; 29 \%)$, The physiological basis of breastfeeding ( $\mathrm{N}=27 / 96 ; 28 \%)$ and Continuing support for infant and young child feeding ( $\mathrm{N}=30 / 112 ; 27 \%)$, but the information contained in textbooks was very brief in comparison to the Model Chapter. In the relevant textbooks, $4.6 \%$ of information was 
found to be correct and thorough (Fig. 1). The topics most thoroughly covered were Animal milks and infant formula and Growth, health and development (Table 1). Topics correctly, albeit briefly, covered composed $17.6 \%$ of the total. The topic most frequently mentioned (five out of eight textbooks) was Medication and drugs, followed by Breast-milk composition, Hormonal control of breast milk production, Creating a supportive environment for breastfeeding, Support for mothers in the community, Assessing the child's growth, Assessing the health of the child and mother in half of the relevant textbooks (Table 1).

Incorrect information was found in all textbooks, with a mean of 5.7\% (range: $3.3-10$ ) (Fig. 1). It most often related to information on Complementary feeding $(\mathrm{N}=3 / 24 ; 13 \%)$ and Management of breast conditions and other breastfeeding difficulties $(\mathrm{N}=18 / 136 ; 13 \%)$. For example, Anatomy of the breast was incorrectly described in all obstetric textbooks as being "structured of 15-20 lobules with a widening of the milk duct under the areola, called the lactiferous sinus" (19); whereas, current evidence describes an average of 9 lobules and no lactiferous sinuses (20). One obstetric textbook stated that "mastitis is caused by infection" (17), while a paediatric textbook advised compulsory antibiotics for mastitis (14), which is contrary to current international clinical protocols that recommend conservative management of mastitis (effective milk removal and supportive measures) as first line therapy, given that milk stasis is considered the primary cause (21).

O\&G and family medicine textbooks omitted between 80 and $90 \%$ of information found in the Model Chapter, whereas paediatric texts omitted up to $67.8 \%$ (Fig. 1). Most topics on Policy, health system and community actions ( $\mathrm{N}=104 / 112 ; 91 \%)$ and Appropriate feeding in exceptionally difficult circumstances $(\mathrm{N}=71 / 80 ; 89 \%)$ were left out in all but one evaluated textbook (Table 1). Table 2 lists the 16 topics from the Model Chapter not covered in any of the assessed textbooks.

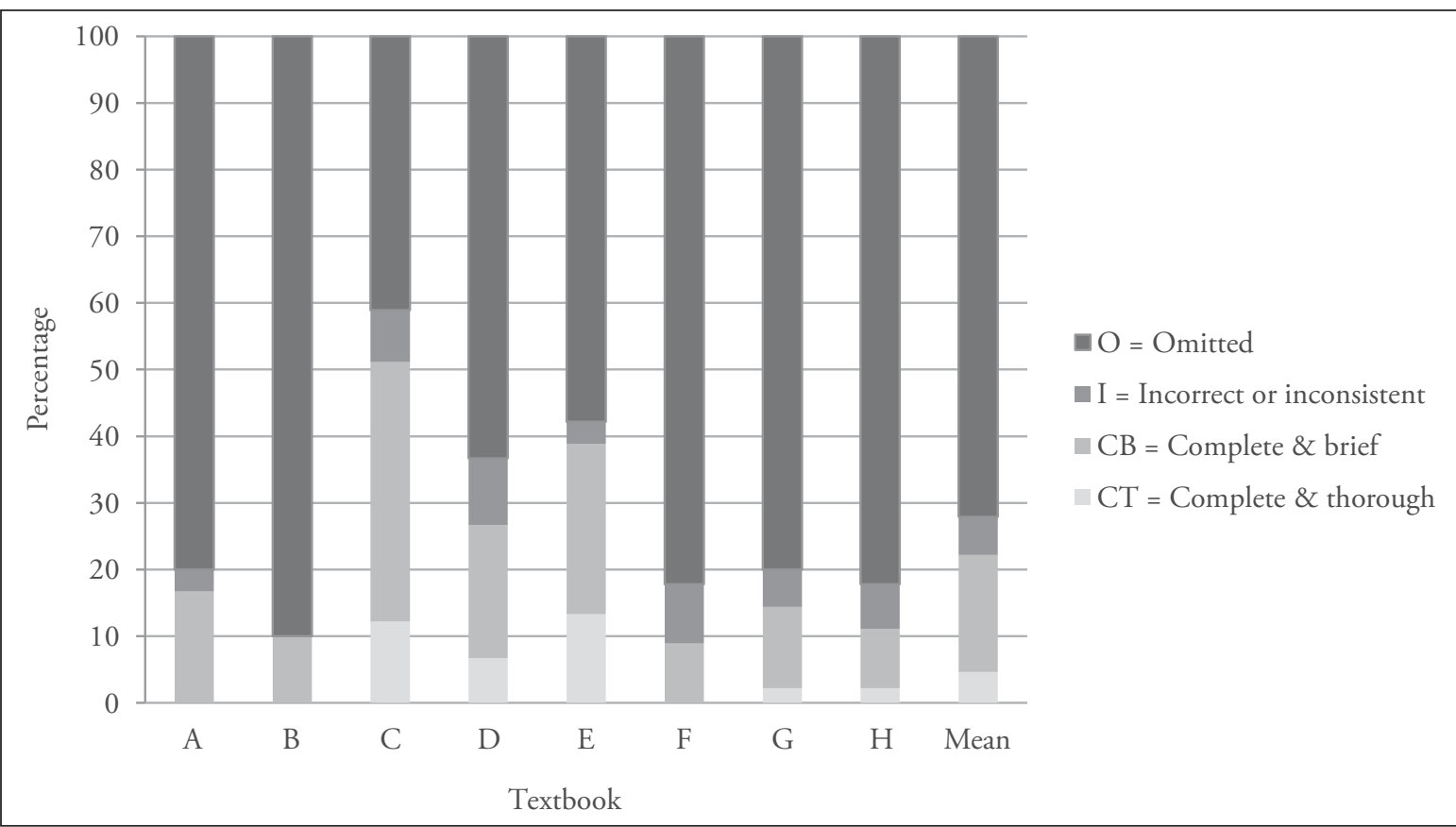

Fig. 1. Scores* (\%) on infant and young child feeding (IYCF) content in family medicine, paediatric and obstetric textbookst in Croatia. *WHO Model Chapter used as "gold standard" for evaluation of IYCF information in selected textbooks †Textbooks analysed: A=Family Medicine (Katić 2013); B=Textbook of family medicine (Rakel 2005); C=Paediatrics (Mardesić 2003); D=Paediatric gastroenterology (Raić 2002); E=Nelson Textbook of Paediatrics (Kliegman et al. 2016); $F=$ Obstetrics (Dražančić 1999); G=Obstetrics (Kuvačić 2009); H=Gynaecology and perinatology (Kurjak 2003). 
Table 1. Scores* on IYCF Topics in Assessed Textbooks

IYCF topics from Model Chapter

Textbooks

Session 1. The importance of infant and young child feeding and recommended practices

1.1 Growth, health and developmen

1.2 The Global Strategy for infant and young child feeding

1.3 Recommended infant and young child feeding practices

1.4 Current status of infant and young child feeding globally

1.5 Evidence for recommended feeding practices- for baby

1.5.1 Evidence for recommended feeding practices-for mother

\begin{tabular}{llllllll}
\hline A & B & C & D & E & F & G & H
\end{tabular}

SESSION 2. The physiological basis of breastfeeding

2.1 Breast-milk composition

$\begin{array}{llllllll}\mathrm{CB} & \mathrm{CB} & \mathrm{CT} & \mathrm{CT} & \mathrm{CT} & \mathrm{CB} & \mathrm{O} & \mathrm{O}\end{array}$

$\begin{array}{llllllll}\mathrm{O} & \mathrm{O} & \mathrm{O} & \mathrm{O} & \mathrm{O} & \mathrm{O} & \mathrm{O} & \mathrm{O}\end{array}$

$\begin{array}{llllllll}\mathrm{O} & \mathrm{O} & \mathrm{I} & \mathrm{I} & \mathrm{CT} & \mathrm{O} & \mathrm{O} & \mathrm{O}\end{array}$

$\begin{array}{llllllll}\mathrm{O} & \mathrm{O} & \mathrm{O} & \mathrm{CB} & \mathrm{CB} & \mathrm{O} & \mathrm{CT} & \mathrm{O}\end{array}$

$\begin{array}{llllllll}\mathrm{O} & \mathrm{CB} & \mathrm{CT} & \mathrm{CB} & \mathrm{CT} & \mathrm{CB} & \mathrm{O} & \mathrm{O}\end{array}$

O

2.2 Colostrum and mature milk

$\begin{array}{llllllll}\mathrm{O} & \mathrm{CB} & \mathrm{CB} & \mathrm{CT} & \mathrm{CB} & \mathrm{O} & \mathrm{CB} & \mathrm{O}\end{array}$

2.3 Animal milks and infant formula

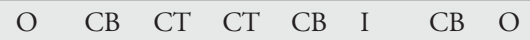

2.4 Anatomy of the breast

2.5 Hormonal control of milk production

$\begin{array}{llllllll}\mathrm{O} & \mathrm{CB} & \mathrm{CT} & \mathrm{CT} & \mathrm{CT} & \mathrm{O} & \mathrm{O} & \mathrm{O}\end{array}$

2.6 Feedback inhibitor of lactation

$\begin{array}{llllllll}\mathrm{O} & \mathrm{O} & \mathrm{O} & \mathrm{O} & \mathrm{O} & \mathrm{I} & \mathrm{I} & \mathrm{I}\end{array}$

2.7 Reflexes in the baby

2.8 How a baby attaches and suckles at the breast

$\begin{array}{llllllll}\mathrm{O} & \mathrm{O} & \mathrm{CB} & \mathrm{CB} & \mathrm{O} & \mathrm{CB} & \mathrm{CT} & \mathrm{CB}\end{array}$

2.9 Effective suckling

2.10 Causes of poor attachment

2.11 Positioning the mother and baby for good attachment

2.12 Breastfeeding pattern

SESSION 3. Complementary feeding:

3.1 Guiding Principles for Complementary Feeding

$\begin{array}{llllllll}\mathrm{O} & \mathrm{O} & \mathrm{O} & \mathrm{O} & \mathrm{O} & \mathrm{O} & \mathrm{O} & \mathrm{O}\end{array}$

$\begin{array}{llllllll}\mathrm{O} & \mathrm{O} & \mathrm{CB} & \mathrm{O} & \mathrm{O} & \mathrm{CB} & \mathrm{O} & \mathrm{O}\end{array}$

$\begin{array}{llllllll}\mathrm{O} & \mathrm{O} & \mathrm{I} & \mathrm{O} & \mathrm{O} & \mathrm{O} & \mathrm{O} & \mathrm{O}\end{array}$

$\begin{array}{llllllll}\mathrm{O} & \mathrm{O} & \mathrm{O} & \mathrm{O} & \mathrm{O} & \mathrm{O} & \mathrm{O} & \mathrm{O}\end{array}$

$\begin{array}{llllllll}\mathrm{CB} & \mathrm{O} & \mathrm{CB} & \mathrm{O} & \mathrm{O} & \mathrm{O} & \mathrm{O} & \mathrm{O}\end{array}$

$\begin{array}{llllllll}\mathrm{O} & \mathrm{O} & \mathrm{CB} & \mathrm{O} & \mathrm{O} & \mathrm{O} & \mathrm{O} & \mathrm{O}\end{array}$

3.2 Recommendations for micronutrient supplementation

$\begin{array}{llllllll}\text { I } & \mathrm{CB} & \mathrm{CB} & \mathrm{I} & \mathrm{CT} & \mathrm{O} & \mathrm{O} & \mathrm{O}\end{array}$

3.3 Local adaptation of complementary feeding recommendations

$\begin{array}{llllllll}\mathrm{I} & \mathrm{O} & \mathrm{I} & \mathrm{I} & \mathrm{CT} & \mathrm{O} & \mathrm{O} & \mathrm{O}\end{array}$

3.3 Local adaptation of complementary feeding recommendations

$\begin{array}{llllllll}\mathrm{O} & \mathrm{O} & \mathrm{O} & \mathrm{CB} & \mathrm{CT} & \mathrm{O} & \mathrm{O} & \mathrm{O}\end{array}$

SESSION 4. Management and support of infant feeding in maternity facilities

\begin{tabular}{|c|c|c|c|c|c|c|c|c|}
\hline 4.1 The Baby-friendly Hospital Initiative & $\mathrm{O}$ & $\mathrm{O}$ & CT & $\mathrm{O}$ & $\mathrm{O}$ & $\mathrm{O}$ & $\mathrm{O}$ & $\mathrm{O}$ \\
\hline 4.2 Policy and training & $\mathrm{O}$ & $\mathrm{O}$ & CB & $\mathrm{O}$ & $\mathrm{CB}$ & $\mathrm{O}$ & $\mathrm{O}$ & $\mathrm{O}$ \\
\hline 4.3 Antenatal preparation & $\mathrm{O}$ & $\mathrm{O}$ & $\mathrm{CB}$ & $\mathrm{O}$ & $\mathrm{CB}$ & $\mathrm{O}$ & $\mathrm{O}$ & $\mathrm{O}$ \\
\hline 4.4 Early contact & $\mathrm{O}$ & $\mathrm{O}$ & $\mathrm{CB}$ & $\mathrm{I}$ & $\mathrm{CB}$ & $\mathrm{O}$ & $\mathrm{O}$ & I \\
\hline 4.5 Showing mothers how to breastfeed & $\mathrm{O}$ & $\mathrm{O}$ & $\mathrm{CB}$ & $\mathrm{I}$ & $\mathrm{CB}$ & $\mathrm{O}$ & $\mathrm{O}$ & $\mathrm{O}$ \\
\hline 4.6 Creating a supportive environment for breastfeeding & $\mathrm{O}$ & $\mathrm{O}$ & $\mathrm{CB}$ & $\mathrm{CB}$ & $\mathrm{CB}$ & $\mathrm{O}$ & $\mathrm{O}$ & $\mathrm{CB}$ \\
\hline 4.7 Follow-up support & $\mathrm{CB}$ & $\mathrm{O}$ & CB & $\mathrm{O}$ & $\mathrm{CB}$ & $\mathrm{O}$ & $\mathrm{O}$ & $\mathrm{O}$ \\
\hline \multicolumn{9}{|l|}{ SESSION 5. Continuing support for infant and young child feeding } \\
\hline 5.1 Support for mothers in the community & $\mathrm{CB}$ & $\mathrm{O}$ & $\mathrm{CB}$ & $\mathrm{CB}$ & $\mathrm{CB}$ & $\mathrm{O}$ & $\mathrm{O}$ & $\mathrm{O}$ \\
\hline 5.2 Infant and young child feeding counselling & $\mathrm{CB}$ & $\mathrm{O}$ & $\mathrm{CB}$ & $\mathrm{O}$ & $\mathrm{CT}$ & $\mathrm{O}$ & $\mathrm{O}$ & $\mathrm{O}$ \\
\hline 5.3 Using good communication and support skills & $\mathrm{CB}$ & $\mathrm{O}$ & $\mathrm{O}$ & $\mathrm{O}$ & $\mathrm{O}$ & $\mathrm{O}$ & $\mathrm{O}$ & $\mathrm{O}$ \\
\hline 5.4 Assessing the situation & $\mathrm{CB}$ & $\mathrm{O}$ & CB & $\mathrm{O}$ & $\mathrm{CB}$ & $\mathrm{O}$ & $\mathrm{O}$ & $\mathrm{O}$ \\
\hline 5.4.1 Assessing the child's growth & $\mathrm{CB}$ & $\mathrm{O}$ & $\mathrm{CB}$ & $\mathrm{CB}$ & $\mathrm{CB}$ & $\mathrm{O}$ & $\mathrm{O}$ & $\mathrm{O}$ \\
\hline 5.4.2 Taking a feeding history & $\mathrm{O}$ & $\mathrm{O}$ & $\mathrm{O}$ & $\mathrm{O}$ & $\mathrm{CB}$ & $\mathrm{O}$ & $\mathrm{O}$ & $\mathrm{O}$ \\
\hline 5.4.3 Observing a breastfeed & $\mathrm{O}$ & $\mathrm{O}$ & $\mathrm{O}$ & $\mathrm{O}$ & $\mathrm{CB}$ & $\mathrm{O}$ & $\mathrm{O}$ & $\mathrm{O}$ \\
\hline 5.4.4 Assessing the health of the child and mother & $\mathrm{CB}$ & $\mathrm{CB}$ & $\mathrm{O}$ & $\mathrm{CB}$ & $\mathrm{CB}$ & $\mathrm{O}$ & $\mathrm{O}$ & $\mathrm{O}$ \\
\hline 5.5 Managing problems and supporting good feeding practices & $\mathrm{CB}$ & $\mathrm{O}$ & $\mathrm{O}$ & $\mathrm{O}$ & $\mathrm{CB}$ & $\mathrm{O}$ & $\mathrm{O}$ & $\mathrm{O}$ \\
\hline
\end{tabular}


Continuation of Table 1. Scores* on IYCF Topics in Assessed Textbooks

IYCF topics from Model Chapter

5.5.1 Refer urgently

5.5.2 Help with difficulties and poor practices

5.5.3 Support good feeding practices

5.5.4 Counsel the mother on her own health, nutrition and fertility

5.6 Follow-up

SESSION 6. Appropriate feeding in exceptionally difficult circumstances

6.1 Low-birth-weight babies

6.1.1 What to feed?

6.1.2 How to feed?

6.1.3 Follow up of LBW babies

6.1.4 Kangaroo mother care

6.2 Severe malnutrition

6.3 Infants and young children living in emergency situations

6.4 Relactation

6.5 Infants of HIV-positive mothers

6.6 Feeding non-breastfed children 6-23 months of age

SESSION 7. Management of breast conditions and other breastfeeding difficulties

\begin{tabular}{|c|c|c|c|c|c|c|c|c|}
\hline 7.1 Full breasts & $\mathrm{O}$ & $\mathrm{O}$ & CT & $\mathrm{O}$ & $\mathrm{CB}$ & $\mathrm{O}$ & $\mathrm{O}$ & CT \\
\hline 7.2 Breast engorgement & $\mathrm{O}$ & $\mathrm{O}$ & $\mathrm{I}$ & $\mathrm{O}$ & $\mathrm{CT}$ & $\mathrm{O}$ & $\mathrm{CB}$ & $\mathrm{CB}$ \\
\hline 7.3 Blocked duct & $\mathrm{O}$ & $\mathrm{O}$ & $\mathrm{CB}$ & $\mathrm{O}$ & $\mathrm{O}$ & $\mathrm{O}$ & $\mathrm{O}$ & $\mathrm{I}$ \\
\hline 7.4 Mastitis & $\mathrm{O}$ & $\mathrm{O}$ & I & $\mathrm{O}$ & $\mathrm{I}$ & $\mathrm{I}$ & $\mathrm{CB}$ & $\mathrm{I}$ \\
\hline 7.5 Breast abscess & $\mathrm{O}$ & $\mathrm{O}$ & $\mathrm{CB}$ & $\mathrm{O}$ & $\mathrm{I}$ & $\mathrm{I}$ & $\mathrm{I}$ & $\mathrm{O}$ \\
\hline 7.6 Sore or fissured nipple & $\mathrm{O}$ & $\mathrm{O}$ & $\mathrm{CT}$ & $\mathrm{I}$ & $\mathrm{CT}$ & $\mathrm{I}$ & $\mathrm{I}$ & $\mathrm{O}$ \\
\hline 7.7 Mastitis, abscess and nipple fissure in an HIV-infected woman & $\mathrm{O}$ & $\mathrm{O}$ & $\mathrm{O}$ & $\mathrm{O}$ & $\mathrm{O}$ & $\mathrm{O}$ & $\mathrm{O}$ & $\mathrm{O}$ \\
\hline 7.8 Candida infection (thrush) in mother and baby & $\mathrm{CB}$ & $\mathrm{O}$ & $\mathrm{CT}$ & $\mathrm{O}$ & $\mathrm{CB}$ & CB & $\mathrm{O}$ & $\mathrm{O}$ \\
\hline 7.9 Inverted, flat, large and long nipples & $\mathrm{O}$ & $\mathrm{O}$ & $\mathrm{CB}$ & I & $\mathrm{O}$ & $\mathrm{O}$ & $\mathrm{CB}$ & $\mathrm{O}$ \\
\hline 7.10 Perceived insufficiency and low breast-milk production & $\mathrm{CB}$ & $\mathrm{O}$ & $\mathrm{CB}$ & I & $\mathrm{CB}$ & $\mathrm{O}$ & $\mathrm{O}$ & $\mathrm{O}$ \\
\hline 7.11 Crying baby & $\mathrm{O}$ & $\mathrm{O}$ & $\mathrm{CB}$ & $\mathrm{CB}$ & $\mathrm{O}$ & $\mathrm{O}$ & $\mathrm{O}$ & $\mathrm{O}$ \\
\hline 7.12 Oversupply of breast milk & $\mathrm{O}$ & $\mathrm{O}$ & $\mathrm{O}$ & $\mathrm{O}$ & $\mathrm{O}$ & $\mathrm{O}$ & $\mathrm{O}$ & $\mathrm{O}$ \\
\hline 7.13 Refusal to breastfeed & $\mathrm{CB}$ & $\mathrm{O}$ & $\mathrm{CT}$ & $\mathrm{O}$ & $\mathrm{O}$ & $\mathrm{O}$ & $\mathrm{O}$ & $\mathrm{O}$ \\
\hline 7.14 Twins & $\mathrm{O}$ & $\mathrm{O}$ & $\mathrm{O}$ & $\mathrm{O}$ & $\mathrm{O}$ & $\mathrm{O}$ & $\mathrm{O}$ & $\mathrm{O}$ \\
\hline 7.15 Caesarean section & $\mathrm{O}$ & $\mathrm{O}$ & $\mathrm{CB}$ & $\mathrm{O}$ & $\mathrm{O}$ & $\mathrm{O}$ & $\mathrm{O}$ & $\mathrm{O}$ \\
\hline 7.16 Mother separated from her baby & $\mathrm{O}$ & $\mathrm{O}$ & $\mathrm{CB}$ & $\mathrm{O}$ & $\mathrm{O}$ & $\mathrm{O}$ & $\mathrm{O}$ & $\mathrm{CB}$ \\
\hline 7.17 Illness, jaundice and abnormality of the child & $\mathrm{CB}$ & $\mathrm{O}$ & $\mathrm{CB}$ & $\mathrm{CB}$ & I & I & $\mathrm{I}$ & $\mathrm{CB}$ \\
\hline \multicolumn{9}{|l|}{ SESSION 8. Mother's health: } \\
\hline 8.1 Mother's Illness & $\mathrm{O}$ & $\mathrm{O}$ & I & CB & CT & $\mathrm{O}$ & CB & I \\
\hline 8.2 Maternal nutrition & $\mathrm{O}$ & $\mathrm{O}$ & CT & CT & $\mathrm{O}$ & I & $\mathrm{O}$ & $\mathrm{O}$ \\
\hline 8.3 Medication and drugs & $\mathrm{O}$ & $\mathrm{O}$ & $\mathrm{CB}$ & CB & $\mathrm{CB}$ & $\mathrm{O}$ & CB & $\mathrm{CB}$ \\
\hline 8.4 Family planning and breastfeeding & $\mathrm{O}$ & $\mathrm{O}$ & $\mathrm{CB}$ & $\mathrm{O}$ & $\mathrm{O}$ & CB & I & $\mathrm{O}$ \\
\hline 8.4.1 Lactational Amenorrhoea Method & $\mathrm{O}$ & $\mathrm{O}$ & $\mathrm{CB}$ & $\mathrm{O}$ & $\mathrm{O}$ & $\mathrm{CB}$ & $\mathrm{CB}$ & $\mathrm{O}$ \\
\hline 8.4.2 Other methods of family planning & $\mathrm{O}$ & $\mathrm{O}$ & $\mathrm{O}$ & $\mathrm{O}$ & $\mathrm{O}$ & $\mathrm{O}$ & $\mathrm{O}$ & $\mathrm{CT}$ \\
\hline \multicolumn{9}{|l|}{ SESSION 9. Policy, health system and community actions } \\
\hline 9.1 Strengthening national policies and legislation & $\mathrm{O}$ & $\mathrm{O}$ & $\mathrm{O}$ & $\mathrm{O}$ & $\mathrm{O}$ & $\mathrm{O}$ & $\mathrm{O}$ & $\mathrm{O}$ \\
\hline 9.1.1 Convention on the Rights of the Child & $\mathrm{O}$ & $\mathrm{O}$ & $\mathrm{CB}$ & $\mathrm{O}$ & $\mathrm{O}$ & $\mathrm{O}$ & $\mathrm{O}$ & $\mathrm{CB}$ \\
\hline
\end{tabular}


Continuation of Table 1. Scores* on IYCF Topics in Assessed Textbooks

\begin{tabular}{|c|c|c|c|c|c|c|c|c|}
\hline \multirow{2}{*}{ IYCF topics from Model Chapter } & \multicolumn{8}{|c|}{ Textbooks $^{\ddagger}$} \\
\hline & A & $\mathrm{B}$ & $\mathrm{C}$ & $\mathrm{D}$ & $\mathrm{E}$ & $\mathrm{F}$ & G & $\mathrm{H}$ \\
\hline $\begin{array}{l}\text { 9.1.2 International Code of Marketing of Breast-milk Substitutes and subsequent relevant } \\
\text { Health Assembly resolutions - the Code }\end{array}$ & $\mathrm{O}$ & $\mathrm{O}$ & $\mathrm{O}$ & $\mathrm{CB}$ & $\mathrm{O}$ & $\mathrm{O}$ & $\mathrm{O}$ & $\mathrm{O}$ \\
\hline 9.1.3 ILO Maternity Protection Convention, 2000 & $\mathrm{O}$ & $\mathrm{O}$ & $\mathrm{O}$ & $\mathrm{O}$ & $\mathrm{O}$ & $\mathrm{O}$ & $\mathrm{O}$ & $\mathrm{CB}$ \\
\hline 9.2 Strengthening the health system and health services & $\mathrm{O}$ & $\mathrm{O}$ & $\mathrm{O}$ & $\mathrm{O}$ & $\mathrm{O}$ & $\mathrm{O}$ & $\mathrm{O}$ & $\mathrm{O}$ \\
\hline 9.2.2 Essential Nutrition Actions & $\mathrm{O}$ & $\mathrm{O}$ & $\mathrm{O}$ & $\mathrm{O}$ & $\mathrm{O}$ & $\mathrm{O}$ & $\mathrm{O}$ & $\mathrm{O}$ \\
\hline 9.3 Strengthening family and community practices & $\mathrm{O}$ & $\mathrm{O}$ & $\mathrm{CB}$ & CT & $\mathrm{O}$ & $\mathrm{O}$ & $\mathrm{O}$ & $\mathrm{O}$ \\
\hline 9.3.1 Behaviour change communication & $\mathrm{O}$ & $\mathrm{O}$ & $\mathrm{O}$ & $\mathrm{O}$ & $\mathrm{O}$ & $\mathrm{O}$ & $\mathrm{O}$ & $\mathrm{O}$ \\
\hline 9.3.2 Training and support of community health workers & $\mathrm{O}$ & $\mathrm{O}$ & $\mathrm{O}$ & $\mathrm{O}$ & $\mathrm{O}$ & $\mathrm{O}$ & $\mathrm{O}$ & $\mathrm{O}$ \\
\hline 9.3.3 Training and support of lay and peer counsellors & $\mathrm{O}$ & $\mathrm{O}$ & $\mathrm{O}$ & $\mathrm{O}$ & $\mathrm{O}$ & $\mathrm{O}$ & $\mathrm{O}$ & $\mathrm{O}$ \\
\hline 9.3.4 Fostering breastfeeding support groups & $\mathrm{O}$ & $\mathrm{O}$ & $\mathrm{O}$ & $\mathrm{O}$ & $\mathrm{O}$ & $\mathrm{O}$ & $\mathrm{O}$ & $\mathrm{O}$ \\
\hline 9.3.5 Health workers' roles in supporting community-based approaches & $\mathrm{O}$ & $\mathrm{O}$ & $\mathrm{CB}$ & $\mathrm{CB}$ & $\mathrm{O}$ & $\mathrm{O}$ & $\mathrm{O}$ & $\mathrm{O}$ \\
\hline 9.4 Assessing progress in coverage of effective interventions & $\mathrm{O}$ & $\mathrm{O}$ & $\mathrm{O}$ & $\mathrm{O}$ & $\mathrm{O}$ & $\mathrm{O}$ & $\mathrm{O}$ & $\mathrm{O}$ \\
\hline Photographs & $\mathrm{O}$ & $\mathrm{O}$ & I & $\mathrm{O}$ & I & $\mathrm{O}$ & $\mathrm{O}$ & I \\
\hline
\end{tabular}

IYCF=Infant and young child feeding; "Scoring code: CT (correct \& thorough); CB (correct \&brief); I (incorrect or inconsistent); O (omitted) information from the text; 'World Health Organization (2009); Infant and Young Child Feeding: Model Chapter for Textbooks for Medical Students and Allied Health Professionals. Geneva: WHO Guidelines Approved by the Guidelines Review Committee; ${ }^{\ddagger}$ The textbooks used: A=Family Medicine (Katić 2013), B=Textbook of family medicine (Rakel 2005), C=Paediatrics (Mardešić 2003), D=Paediatric gastroenterology, (Raić 2002), E=Nelson Textbook of Paediatrics (Kliegman et al. 2016), F=Obstetrics (Dražančić 1999), G=Obstetrics (Kuvačić 2009), H=Gynaecology and perinatology (Kurjak 2003).

\section{Table 2. Topics on IYCF content from Model Chapter} omitted in all assessed textbooks ${ }^{\dagger}$

\begin{tabular}{l}
\hline 1. The Global Strategy for infant and young child feeding \\
\hline 2. When to refer urgently \\
\hline 3. Follow up of LBW babies \\
\hline 4. Kangaroo mother care \\
\hline 5. Severe malnutrition \\
\hline 6. Infants and young children living in emergency situations \\
\hline 7. Relactation \\
\hline 8. Mastitis, abscess and nipple fissure in an HIV-infected woman \\
\hline 9. Oversupply of breast milk \\
\hline 10. Twins \\
\hline 11. Strengthening national policies and legislation \\
\hline 12. Behaviour change communication \\
\hline 13. Training and support of community health workers \\
\hline 14. Training and support of lay and peer counsellors \\
\hline 15. Fostering breastfeeding support groups \\
\hline 16. Assessing progress in coverage of effective interventions \\
\hline
\end{tabular}

IYCF=infant and young child feeding; World Health Organization. Infant and Young Child Feeding: Model Chapter for Textbooks for Medical Students and Allied Health Professionals. Geneva: WHO Guidelines Approved by the Guidelines Review Committee, 2009. 'The textbooks used: Family Medicine (Katić 2013), Textbook of family medicine (Rakel, 2005), Paediatrics (Mardešić 2003), Paediatric gastroenterology, (Raić 2002), Nelson Textbook of Paediatrics (Kliegman et al. 2016), Obstetrics (Dražančić 1999), Obstetrics (Kuvačić 2009), Gynaecology and perinatology (Kurjak 2003).

\section{Discussion}

In our study we found that Croatian physicians' post-graduate training programs in paediatrics and family medicine included information on IYCF, whereas the O\&G curriculum did not list IYCF anywhere. Incorrect information was found in all textbooks, with three quarters of recommended information omitted. In the analysed textbooks, $4.6 \%$ of information was found to be correct and thoroughly covered, whereas $17.6 \%$ was correct but incomplete. Given the rising awareness of the role of nutrition in health promotion and disease prevention, this seems far from adequate.

Training programs in O\&G did not list IYCF anywhere in their official curriculum and surprisingly little information on the Management and support of infant feeding in maternity facilities was found in obstetric textbooks. This is worrying, given the numerous opportunities and important role O\&Gs play in influencing maternal decision making (22). In addition, obstetricians are vital for supporting the Baby-Friendly Hospital Initiative (BFHI) (23), yet despite this initiative being launched in Croatia in 1993 (24), and worldwide 
in 1991, it is still not part of the official O\&G training program. This may contribute to the wrong perception that IYCF is primarily in the domain of midwives and nurses. Feldman-Winter et al. found that when $O \& G$ trainees were exposed to a targeted breastfeeding curriculum, not only they were more likely to show improvements in knowledge, practice patterns related to breastfeeding and confidence, but also infants were more likely to be exclusively breastfed at six months (25).

In our study, most information in commonly used family medicine, paediatric and $O \& G$ textbooks was omitted, and when present usually insufficient. Not a single textbook mentioned the Global Strategy for Infant and Young Child Feeding (26), a seminal WHO/UNICEF document published in 2003 aimed at improving - through optimal feeding - the nutritional status, growth and development, health, and thus the very survival of infants and young children worldwide. In this document, the importance of EBF for the first six months of life is emphasized: only one of the eight evaluated textbooks recommended EBF for six months (16), the others recommending 4 months, even though the majority of textbooks were published after 2003. Interestingly, even though most texts mention the importance of breastfeeding, the topic most thoroughly covered is Animal milks and infant formula, while other topics such as How a baby attaches and suckles at the breast and Oversupply of breast milk are completely omitted.

Using good communication and support skills and Behaviour change communication were barely touched upon in the assessed textbooks but are likely to be covered in other more horizontal teaching activities or basic courses and thus, may be considered a minor omission. On the other hand, Taking a feeding history, Observing a breastfeed and Signs of effective suckling, must be taught specifically in the considered textbooks as essentials skills if physicians are to adequately assess a breastfeeding dyad. Despite this, these topics were largely omitted.

Emergency situations can arise anywhere, anytime and health services need to be prepared to protect and support optimal IYCF. Breastfeeding in these circumstances can be lifesaving and yet the session Infants and young children living in emergency situations was not present in any of the eight assessed textbooks. Relactation in these situations is often beneficial; therefore, doctors should be aware of this option and yet this topic was omitted from all textbooks. Appropriate feeding of premature infants, another at risk population, is crucial for their development and survival but topics such as Follow up of low birth weight babies and Kangaroo mother care were not even mentioned.

\section{Limitations of the Study}

A limitation of this study is that we did not assess handouts provided by individual teachers or other teaching materials. To be fair, these materials may possibly contain more comprehensive, up-to-date and accurate information on IYCF but they raise the question of quality and heterogeneity of teaching materials between institutions and how this impacts later practice. Despite this limitation, our study is the first to analyse IYCF content in paediatric, family medicine and $O \& G$ training programs in Croatia and it is the first study to compare IYCF information in physicians' textbooks with the WHO Model Chapter.

\section{Conclusion}

Minimal hours of teaching on IYCF were included in national training programs for physicians who care for women and children in Croatia. Textbooks used for the training of these health professionals were outdated and contained incorrect or at best, incomplete information on IYCF. Given the influential role doctors have, it is essential that they possess the knowledge and skills to adequately inform and support families in regard to IYCF. This will only be possible if teaching time is allocated to this topic and relevant textbooks are up-to-date, evidence-based and comprehensive. The WHO Model Chapter may help achieve this goal.

Acknowledgements: The authors thank professor Livia Puljak for editing the manuscript. 
Authors' Contributions: Conception and design: IZG and AĆG; Acquisition, analysis and interpretation of data: AĆG and IZG; Drafting the article: AĆG and IZG; Revising it critically for important intellectual content: IZG and AĆG; Approved final version of the manuscript: AĆG and IZG.

Conflict of Interest: The authors declare that they have no conflict of interest.

\section{References}

1. Hansen K. Breastfeeding: a smart investment in people and in economies. Lancet. 2016;387(10017):416.

2. Victora CG, Bahl R, Barros AJ, Franca GV, Horton $S$, Krasevec $\mathrm{j}$ et al. Breastfeeding in the 21st century: epidemiology, mechanisms and lifelong effect. Lancet. 2016;387(10017):475-90.

3. Zakarija-Grković I, Boban M, Janković S, Ćuže A, Burmaz T. Compliance with WHO/UNICEF BFHI Standards in Croatia After Implementation of the BFHI. J Hum Lact. 2017;34(1):106-15.

4. Nakar S, Peretz O, Hoffman R,Grossman Z, Kaplan B, Vinker S. Attitudes and knowledge on breastfeeding among paediatricians, family physicians, and gynaecologists in Israel. Acta Paediatr. 2007;96(6):848-51.

5. Leavitt G, Martínez S, Ortiz N, Garcia L. Knowledge about breastfeeding among a group of primary care physicians and residents in Puerto Rico. J Community Health. 2009;34(1):1-5.

6. Brodribb W, Fallon T, Jackson C, Hegney D. Attitudes to infant feeding decision-making-a mixed-methods study of Australian medical students and GP registrars. Breastfeed Rev. 2010;18(1):5-13.

7. Freed GL, Clark SJ, Lohr JA, Sorenson JR. Pediatrician involvement in breastfeeding promotion: a national study of residents and practitioners. Pediatrics. 1995;96(3):490-94.

8. Zakarija-Grkovic I, Burmaz T. Effectiveness of the UNI$\mathrm{CEF} / \mathrm{WHO}$ 20-hour course in improving health professionals' knowledge, practices, and attitudes to breastfeeding: before/after study of 5 maternity facilities in Croatia. Croat Med J. 2010;51(5):396-405.

9. Ogburn T, Philipp BL, Espey E, Merewood A, Espindola $\mathrm{D}$. Assessment of breastfeeding information in general obstetrics and gynecology textbooks. J Hum Lact. 2011;27(1):58-62.

10. Philipp BL, Merewood A, Gerendas EJ, Bauchner H. Breastfeeding information in pediatric textbooks needs improvement. J Hum Lact. 2004;20(2):206-10.

11. WHO. Infant and Young Child Feeding: Model Chapter for Textbooks for Medical Students and Allied Health
Professionals. Geneva, WHO Guidelines Approved by the Guidelines Review Committee. 2009.

12. Katić M, Švab I. Katić M, Švab I. Family medicine [in Croatian]. Zagreb: Alfa; 2013. Zagreb: Alfa; 2013.

13. Rakel RE. Rakel RE. Textbook of family medicine [in Croatian]. Zagreb: Naklada Ljevak; 2013. Zagreb: Naklada Ljevak; 2013.

14. Mardešić D. Mardešić D. Paediatrics [in Croatian]. Zagreb: Školska knjiga; 2003. Zagreb: Školska knjiga; 2003.

15. Raić F, Votava-Raić A. Raić F, Votava-Raić A. Paediatric gastroenterology [in Croatian]. Zagreb: Naklada Ljevak; 2002. Zagreb: Naklada Ljevak; 2002.

16. Kliegman RM, Stanton BF, St Geme JW, Scholar N. Nelson Textbook of Pediatrics. 20th ed., Philadelphia (PA): Elsevier; 2016.

17. Dražančić A. Dražančić A. Obstetrics [in Croatian]. Zagreb: Školska knjiga; 1999. Zagreb: Školska knjiga; 1999.

18. Kuvačić I, Kurjak A, Đelmiš J. Kuvačić I, Kurjak A, Đelmiš J. Obstetrics [in Croatian]. Zagreb: Medicinska naklada; 2009. Zagreb: Medicinska naklada; 2009.

19. Kurjak A. Kurjak A. Gynaecology and perinatology [in Croatian]. Varaždinske Toplice: Tonimir; 2003. Varaždinske Toplice: Tonimir; 2003.

20. Ramsay DT, Kent JC, Hartmann RA, Hartmann PE. Anatomy of the lactating human breast redefined with ultrasound imaging. J Anat. 2005;206(6):525-34.

21. Amir LH. 2014. ABM Clinical Protocol \#4: Mastitis, Revised March Breastfeed Med. 2014;9(5):239-43.

22. ACOG. Committee Opinion No. 658: Optimizing Support for Breastfeeding as Part of Obstetric Practice. Obstet Gynecol. 2016;127(2):e86-92.

23. WHO and UNICEF. Baby-friendly Hospital Initiative: Revised, Updated and Expanded for Integrated Care. 2009. [cited 2018 April 11]. Available at: http://www. who.int/nutrition/publications/infantfeeding/bfhi_trainingcourse/en/

24. Grgurić J, Zakarija-Grković I, Pavičić Bošnjak A, Stanojević M. A Multifaceted Approach to Revitalizing the Baby-Friendly Hospital Initiative in Croatia. J Hum Lact. 2016;32(3):568-73.

25. Feldman-Winter L, Barone L, Milcarek B,Hunter K, Meek J, Morton J, Williams T, Naylor A, Lawrence RA. Residency curriculum improves breastfeeding care. Pediatrics. 2010;126: 289-97.

26. WHO and UNICEF. Global strategy for infant and young child feeding. 2003. [cited 2018 April 11]. Available at: http://www.who.int/nutrition/publications/infantfeeding/9241562218/en/ 